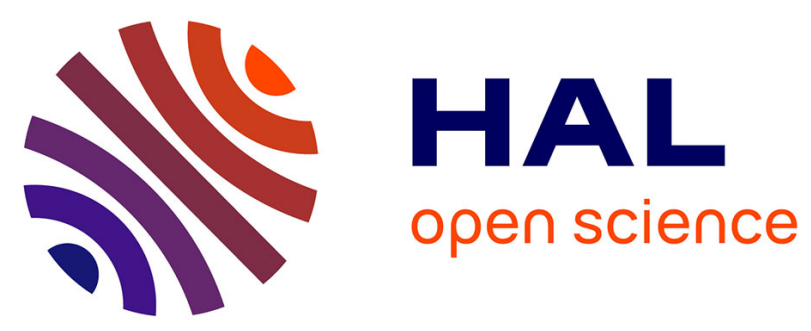

\title{
Flammability of some ornamental species in wildland-urban interfaces in southeastern France: laboratory assessment at particle level
}

\author{
A. Ganteaume, M. Jappiot, C. Lampin, M. Guijarro, C. Hernando
}

\section{To cite this version:}

A. Ganteaume, M. Jappiot, C. Lampin, M. Guijarro, C. Hernando. Flammability of some ornamental species in wildland-urban interfaces in southeastern France: laboratory assessment at particle level. Environmental Management, 2013, 52, p. 467 - p. 480. 10.1007/s00267-013-0067-z . hal-00941751

\section{HAL Id: hal-00941751 \\ https://hal.science/hal-00941751}

Submitted on 4 Feb 2014

HAL is a multi-disciplinary open access archive for the deposit and dissemination of scientific research documents, whether they are published or not. The documents may come from teaching and research institutions in France or abroad, or from public or private research centers.
L'archive ouverte pluridisciplinaire $\mathbf{H A L}$, est destinée au dépôt et à la diffusion de documents scientifiques de niveau recherche, publiés ou non, émanant des établissements d'enseignement et de recherche français ou étrangers, des laboratoires publics ou privés. 
Author-produced version of the article published in Environmental Management, 2013, vol. 52, pp 467-480 Original publication available at http://www.springer.com doi : 10.1007/s00267-013-0067-z11

\section{Flammability of some ornamental species in wildland-urban interfaces in Southeastern} France: laboratory assessment at particle level.

Anne Ganteaume ${ }^{\mathrm{A}, \mathrm{C}}$, Marielle Jappiot ${ }^{\mathrm{A}}$, Corinne Lampin $^{\mathrm{A}}$, Mercedes Guijarro ${ }^{\mathrm{B}}$, Carmen Hernando ${ }^{\mathrm{B}}$

A Irstea. UR EMAX, 3275 route de Cézanne, CS 40061, 13182 Aix-en-Provence, France

${ }^{\text {B }}$ INIA. Forest Research Centre. Dpt. of Silviculture and Forest Management. Ctra. A Coruña km 7.5. 28040

Madrid, Spain

${ }^{\mathrm{C}}$ Corresponding author: anne.ganteaume@irstea.fr

Tel.: +33442666979

Fax: +33442669923 
Assessment of the flammability of ornamental vegetation (particularly hedges) planted around houses is necessary in light of the increasing urbanization of the wildland-urban interfaces (WUIs) and the high fire occurrence in such areas. The structure and flammability of seven of the species most frequently planted as hedges in Provence (Southeastern France) were studied at particle level. Spatial repartition of the different types of fuel particles within plants was assessed by means of the Cube Method. The leaf flammability was assessed using an epiradiator as a burning device and measurements of foliar physical characteristics and gross heat of combustion (GHC) helped to explain the results of burning experiments. Co-inertia analysis revealed that species with thin leaves were quick to ignite (Pyracantha coccinea, Phyllostachys sp.) and species with high leaf GHC burned the longest (Pittosporum tobira, Nerium oleander). Species presenting high ignitability (Photinia fraseri, Phyllostachys sp. and Pyracantha coccinea) were characterised by high foliar surface area-to-volume ratio, and species presenting lower ignitabilitywere characterised by high GHC (Pittosporum tobira, Nerium oleander, Cupressus sempervirens). Hierarchical cluster analysis of the flammability variables (ignition frequency, time-to-ignition and flaming duration) categorized the relative flammability of the seven species (including dead Cupressus sempervirens) in five clusters of species from poorly flammable (Pittosporum tobira) to extremely flammable (dead Cupressus sempervirens).This study provides useful information for reducing fire risk in WUIs in the study area.

\section{Additional Key-words: ORNAMENTAL VEGETATION, FLAMMABILITY PARAMETERS, PLANT PARTICLES, FIRE HAZARD, WILDLAND-URBAN INTERFACE}

\section{Introduction}

Around the world, concerns about the impact of wildland fires are increasingly focusing on the wildland-urban interface (WUI), where their occurrence is high and where they can affect people and structures (Etlinger and Beall, 2004). Fires in wildland-urban interfaces regularly destroy dwellings when fuel and weather are conducive to fire (Covington 2000) and human-caused fire ignitions are most common in these areas (Cardille et al. 2001; Jappiot et al. 2001; Lampin et al. 2006a, 2006b). As a result, WUIs are now considered as priority areas for controlling wildfire (Stephens 2005). In the Mediterranean region, the incidence of fire is often higher in wildland-urban interfaces and in wildland/network interfaces because of high urban pressure and accumulation of wildland biomass (Davis 1990; Vélez 1997; Cohen 2000; Leone et al. 2003; de la Riva and Pérez-Cabello 2005; de la Riva et al. 2006; Jappiot et al. 2007; Lampin-Maillet 2009). Furthermore, the higher incidence of extreme climate events (very high summer temperatures, strong winds and drought periods) expected under climate change, together with the high flammability of Mediterranean fuels, implies higher probability of ignition (Valette 1990; Dimitrakopoulos and Papaioannou 2001).

The presence of ornamental vegetation around houses is one of the major concerns regarding the vulnerability of structures as this vegetation can act as "ladder fuel" and ignite houses and other structures (Etlinger and Beall 2004). Therefore, less flammable species are recommended as ornamental plants (Monroe et al. 2003). According to Dimitrakopoulos (2001) and Dimitrakopoulos and Papaiannou (2001), classification of fuel in relation to its expected flammability is an essential component of fire hazard assessment. Homeowners in WUIs are often advised to minimize or eliminate the use of highly flammable vegetation when landscaping their homes, and lists containing species that are appropriate for use in fire-wise landscaping are often requested. Reducing the fire hazard associated with vegetation can be accomplished by appropriate arrangement, maintenance and selection of species. However, Lubin and Shelly (1997) highlighted many discrepancies in the recommendations for plant selection by species, which often relied on anecdotal information with little scientific basis, largely because of the scarcity of scientific data on the flammability of ornamental vegetation. Nonetheless, there is an increasing demand from forest managers, fire managers and fire-fighters for scientifically based information about ornamental species for use in WUIs. 
Although losses of WUI vegetation and structures are substantial and are increasingly common, studies on fire performance of ornamental plants, performed mainly in USA (White et al. 1996; Irby et al. 2000; Beall 2001; White et al. 2002; Monroe et al. 2003; Etlinger and Beall 2004; Weise et al. 2005), have not been carried out in Europe. Some of the early studies sought to identify slow-burning plants that could survive in southern California, e.g. plants with high mineral content that could act as fire-retardant plants (Ching and Stewart 1962) and plant species with low fuel volume (Nord and Green 1977). More recent studies (Etlinger 2000; Etlinger and Beall 2004) have focused on the relationship between plant characteristics and flammability components as defined by Anderson (1970) and Martin et al. (1994).

Plant flammability has been widely studied and experimentally assessed in the laboratory for various purposes, following several methods which took into account many different definitions and flammability parameters. Moreover, methods which allowed the assessment of vegetation flammability and the results obtained differed depending on the scale considered (Etlinger and Beall, 2004; Madrigal et al., 2012). However, the combination of different methods for assessing the flammability parameters of ornamental vegetation as well as the description of its structure, have not been studied yet.

In WUIs, two types of fire ignition can occur regarding ornamental vegetation: (i) ignition of the vegetation directly subjected to the intensity of the flame front, as assessed in the present study (flammability at particle level), and (ii) in case of spot-fire, ignition of the litter (ignition of dead surface fuel) by a glowing firebrand that lands at the foot of the plant. The flammability of dead surface fuels, i.e. litter, that could be ignited during a spot fire, has been assessed in a previous study (Ganteaume et al. 2012).

The objective of this work was to compare the potential flammability of some ornamental plants that could be used as hedges for instance in Provence (SE France), taking into account the plant structure, some variables of flammability and the gross heat of combustion of fine particles. According to the classical definition (Anderson, 1970), flammability was considered as the result of ignitability (time until ignition), combustibility (rapidity of the combustion after ignition) and sustainability (ability to sustain combustion once ignited). Therefore, live leaf flammability was assessed by determining time-to-ignition, flaming duration and ignition frequency.

\section{Material and methods}

\subsection{Study area and selection of species}

Bouches du Rhône is one of the French “départements” which is located in eastern Provence (Fig. 1) and is one of the areas most seriously affected by wildfires in SE France (forest fire database Prométhée, www.promethee.com). The climatic conditions differ in the coastal fringe and in the inland part of the département (Météo France database, www.meteofrance.com); thus, the species planted as hedges will also differ depending on the location. Therefore, the study area was divided into two sub-areas (coastal and inland) for the purposes of sampling. To identify the main species used as ornamental vegetation, a survey of hedges was made in nine locations in both areas, taking into account a total of 117 hedges in four coastal locations and 110

hedges

in

five

inland

locations

(Fig.

$1)$. 
Author-produced version of the article published in Environmental Management, 2013, vol. 52, pp 467-480

Original publication available at http://www.springer.com
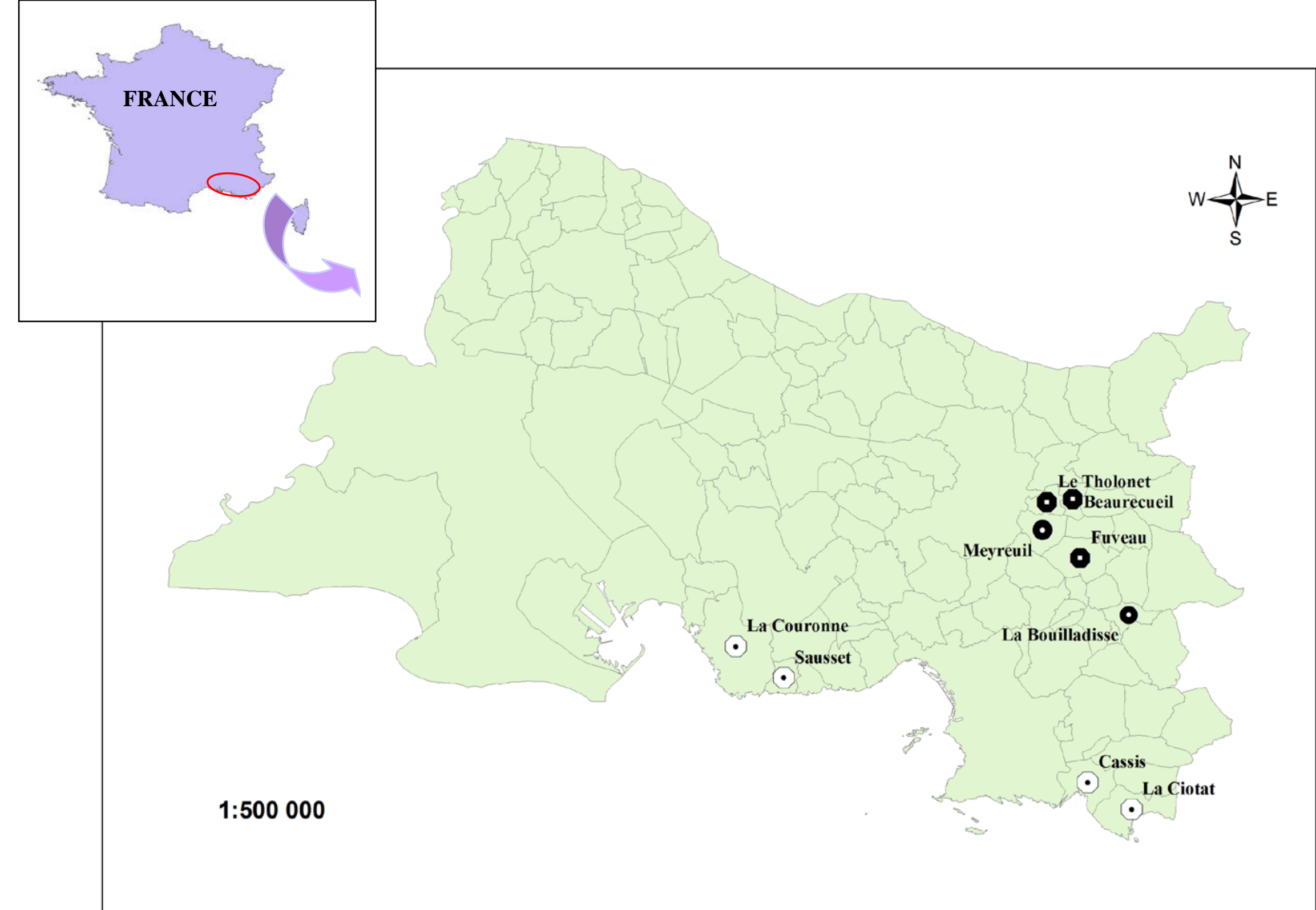

Fig. 1 Map of the study area (Département des Bouches du Rhône) in Southeastern France showing where the hedges were surveyed (BD Carto). White spots: coastal area, black spots: inland area 
A total of 20 species were recorded during the survey and were considered representative of the species planted in the whole study area. Seven of these species were chosen for the present study, either because they were the most frequent species planted as hedges (Prunus laurocerasus, Pyracantha coccinea, Cupressus sempervirens, Nerium oleander, Photinia fraseri and Pittosporum tobira) or because of their singularity, like Phyllostachys sp., a type of bamboo, which may have particular flammability characteristics.

\subsection{Field samplings}

The species were sampled in summer (between July and August 2011) during the fire season, when the fuel moisture content is lowest and the fire risk is highest.

Fuel sampling at particle level

The sampling of particles (mainly leaves and twigs) was performed according to the "cube method" (Cohen et al. 2002). This method allowed us to determine the structure of the plant (proportion and spatial distribution of live and dead fuel particles of different sizes within the plant canopy) by use of a $0.008 \mathrm{~m}^{3}$ cube (20 x 20 x 20 $\mathrm{cm}$ ). The cube was placed on the plant, at breast height, at the base, the centre and the top of the plant and the biomass filling the cube was sampled (Fig. 2). For each species, the sampling was replicated in three different plants in the hedge.

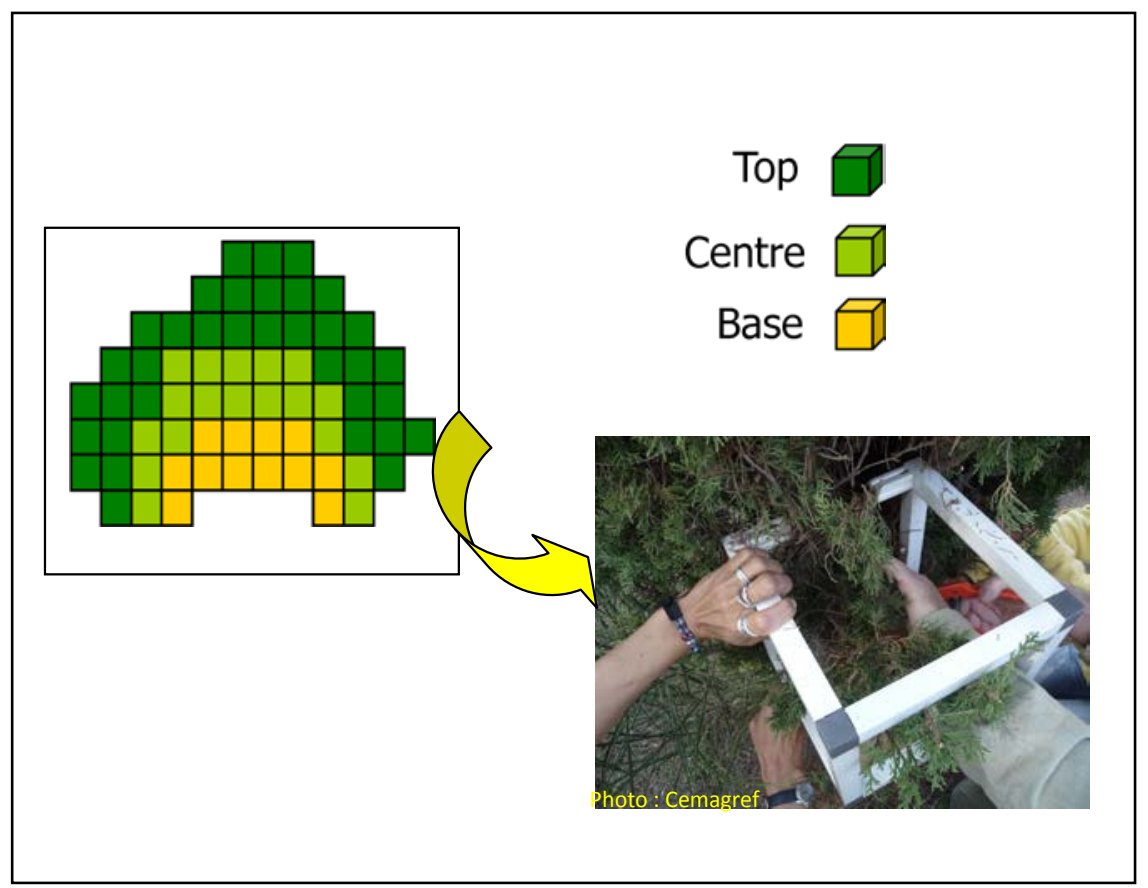

Fig. 2 Shape of the plant designed by three locations of cube (top, centre and base) and biomass sampling in a Cypress "top” cube

\section{$\underline{\text { Sampling of leaves for flammability experiments }}$}

To characterise the flammability of the live fuel according to the protocol proposed by Valette (1990), the leaves of each species were sampled homogeneously, and only leaves of the same age and size were collected. Because of the high proportion of dead fuel sampled within the canopy of Cupressus sempervirens, dead leaves were also sampled for this species. To ensure that the fuel moisture content (FMC) was minimal, in order to be in the worst case scenario in term of fire risk, each species was sampled in summer at the hottest time of the day (between 12 
am and $2 \mathrm{pm}$ ) and the sampling was not carried out on days following rainfall events (Valette 1990). The leaves sampled were placed in plastic bags and stored in a cool box for transportation to the laboratory, minimizing changes in water content.

Before burning, the physical characteristics of the live leaves of the different species (mass, surface, volume and surface-to-volume ratio) were measured because the importance of particle geometry in determining the combustion of fuel particles. To characterize the leaf surface exposed to hot gases and fire during combustion, leaf thickness was measured avoiding thick veins. Leaf surface area was measured using a $2400 \mathrm{dpi}$ scanner and image analysis software. Particle thickness was measured using a $10^{-4} \mathrm{~m}$ accuracy micrometer.

\subsection{Description of laboratory protocols}

\section{Sorting of particles sampled by the "cube method"}

In the laboratory, the samples were oven-dried $\left(48 \mathrm{~h}\right.$ at $60^{\circ} \mathrm{C}$ ) until the dry weight did not change (FMC $<5 \%$ ), then the particles were sorted into four classes and weighed: (i) leaves, (ii) particles $<2 \mathrm{~mm}$ in diameter, (iii) particles 2-6 mm, and (iv) particles $>6 \mathrm{~mm}$. Particles were mainly composed of twigs and fractions of fruits. Very fine fuel was composed of leaves and particles $<2 \mathrm{~mm}$ and fine fuel was composed of leaves and particles up to $6 \mathrm{~mm}$ in diameter. Dead particles, that may affect the flammability, were separated from live particles in order to have available both proportions within a species. Bulk density was calculated as the dry weight of particles divided by the volume of the cube and expressed in $\mathrm{kg} \mathrm{m}^{-3}$. Bulk density was used to refer to the amount of fuel in a volume of airspace, for each class of particle, each cube location and each species.

\section{Flammability experiments with the epiradiator}

The epiradiator device consisted of a $500 \mathrm{~W}$ electric radiator with a $10 \mathrm{~cm}$ diameter radiant disk. The surface temperature achieved with the device at steady-state regime was $420{ }^{\circ} \mathrm{C}$ (Fig. 3). Fifty samples (each weighing $1 \mathrm{~g}$ ) of live leaves of each species studied (and dead leaves of Cupressus sempervirens) were exposed to the heat source (Valette 1990). Use of larger fuel masses may increase the possibility that other fuel properties, such as fuel height on the epiradiator, would cause differences in flammability (Hernando 2000; Petriccione et al. 2006; Pellizzaro et al. 2007). The samples were in direct contact with the electric radiator, and the surface area of contact depended on the species. The surface in contact with the epiradiator was assumed to be close enough to the heat source to undergo homogeneous heat transfer effects. A pilot flame, which did not take part in decay of the sample, was located $4 \mathrm{~cm}$ above the centre of the disk and allowed more regular ignition of the gases emitted during combustion of the leaf. The device was placed under a hood to prevent air currents perturbing the convection column and gas plumes. Once the leaf samples were placed on the electric radiator, time to ignition (TTI) and flame extinction were recorded to enable calculation of the flaming duration (FD) of the sample. The ignition frequency (IF) was calculated as the percentage of tests in which the samples ignited. Each species was classified according to its ignition frequency and its mean time to ignition following the classification outlined by Valette (1990) which combined ignition frequency ranging from $<50 \%$ to $>95 \%$ and time-to-ignition ranging from $<12.5 \mathrm{~s}$ to $>32.5 \mathrm{~s}$ and then rated the species from 0 to 5 ( $0=$ slightly flammable; 1 = weakly flammable; 2 = moderately flammable; 3 = flammable; $4=$ highly flammable; $5=$ extremely flammable).

Before the experiments, a $5 \mathrm{~g}$ sample (fresh weight) of each species was oven-dried for $24 \mathrm{~h}$ at $60^{\circ} \mathrm{C}$ to enable calculation of the FMC according to the following equation:

FMC $(\%)=($ Fresh weight $(\mathrm{g})-$ Dry weight $(\mathrm{g})) /$ Dry weight $(\mathrm{g}) * 100$ 


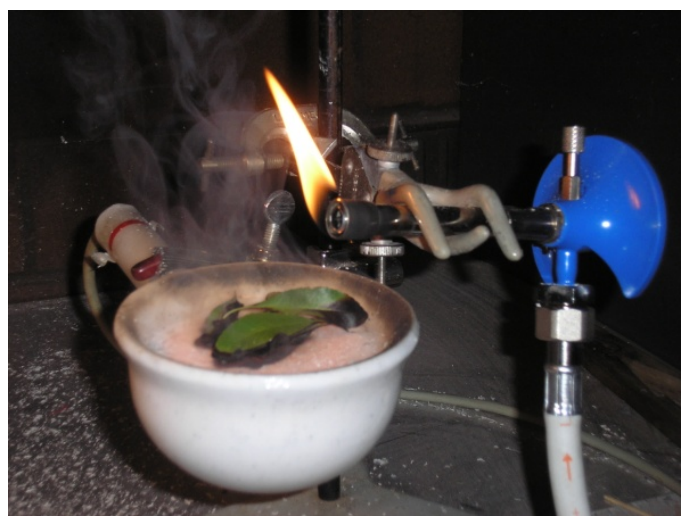

Fig. 3 Epiradiator used in the flammability experiments

\section{$\underline{\text { Gross heat of combustion of very fine fuel }}$}

Gross heat of combustion (GHC) of the very fine live fuel ${ }^{1}$ (composite samples of leaves and particles $<2 \mathrm{~mm}$ in diameter formed from all cubes collected within a species) was determined following Spanish Standard UNE 164001 EX (Asociación Española de Normalización y Certificación 2005). All fuel samples were ground individually to $5 \cdot 10^{-4} \mathrm{~m}$ in a mill. A hand press was used to make the ground material into 1 g-pellets, which were then oven-dried at $100 \pm 5^{\circ} \mathrm{C}$ for $24 \mathrm{~h}$ and weighed. Measurements were made with an IKA®C5000 adiabatic bomb calorimeter with a platinum resistance sensor (PT-100). Both mill and hand press were also manufactured by IKA ${ }^{\circledR}$. For each type of particle, the same measurements were made on two samples. A third sample was included whenever the difference between the first two values was more than $2 \%$ of the mean value.

\subsection{Data analyses}

The effects of the species and of the cube location (sampled at the base, centre or top of the plant) on the proportions of the different classes of particle and on the flammability variables (TTI, FD, IF) were analyzed by two-way and one-way (when non-parametric tests were used) analyses of variance (ANOVA). In addition to the tests of overall significance with ANOVA, the LSD test was used to check for significant differences between the different means. A significant difference between the variables was assumed when the p-value was $\leq 0.05$. Some of the variables were previously log-transformed to meet ANOVA assumptions of normality and homoscedasticity. In all cases, when the data distribution did not follow the expected parametric pattern or when a test condition provided insufficient data, a non-parametric Kruskal-Wallis test was used instead of a parametric Fisher test. All species and cube locations were tested at random as well as their interaction. During the experiments, the mean relative temperature was $23.6^{\circ} \mathrm{C}$ and mean relative humidity was $52 \%$ but these variables did not affect flammability (Fisher's LSD test, $\mathrm{p}>0.05$ ). All analyses were performed using Statgraphics Centurion XV.

Co-inertia analysis (Dolédec and Chessel 1994), suited to large number of variables compared with small number of samples, was performed on the dependent variables (flammability variables) and on the explanatory variables (leaf traits and leaf GHC) to examine associations between leaf characteristics and leaf flammability. The complete matrix of data was transferred to the statistical package under $\mathrm{R}$ 2.5.1 (R Development Core Team, 2005) then analyzed using the ADE-4 package (Thioulouse et al. 1997). Co-inertia is a statistical method commonly used to analyze the relationship between species and environmental variables (e.g. Moretti and Legg 2009). The first step of the co-inertia analysis (Ter Braak and Schaffers 2004) was to conduct a correspondence analysis (CA) on the leaf characteristics, then a principal component analysis (PCA) on the flammability variables. A factorial plane was thus created and enabled a new ordination of each data set. The

${ }^{1}$ The GHC of the very fine dead fuel was also measured for Cupressus sempervirens because of the high fraction of dead fuel recorded in this species. 
statistical significance of each effect or combination of effects has been tested using a Monte-Carlo permutation test with 1000 permutations using the 'coin' package on R. High sums of eigen values on the main axes indicate high correlation among datasets. Hierarchical cluster analysis of the flammability variables was performed to rank the seven species (including dead Cupressus sempervirens) according to their flammability. These multivariate analyses were performed with R software (R 2.11-1, ADE-4 1.5-1 package).

\section{Results}

\subsection{Cube Method}

The bulk densities of the most flammable classes of particles (leaves and particles $<2 \mathrm{~mm}$ ) sampled in each cube location for the seven species studied are shown in Table 1. Regarding live particles, the highest bulk densities were located in the top and centre cubes. Cupressus sempervirens and Prunus laurocerasus presented the highest values (respectively 7.87 and $6.31 \mathrm{kgm}^{-3}$ in total) contrary to Pyracantha coccinea and Phyllostachys sp. (respectively 0.96 and $0.93 \mathrm{kgm}^{-3}$ in total). Regarding dead particles, Cupressus sempervirens presented huge amount of dead leaves, especially located in base cubes $\left(10.36 \mathrm{kgm}^{-3}\right.$ for a total of $\left.11.12 \mathrm{kgm}^{-3}\right)$. There was no dead fuel in the cubes sampled in Nerium oleander, Photinia fraseri and Phyllostachys sp. ; bulk densities of dead particles were very low in the other species $\left(<0.15 \mathrm{kgm}^{-3}\right.$ in total $)$.

The species and the cube location significantly affected the proportions of live leaves, particles $<2 \mathrm{~mm}$ and $>6 \mathrm{~mm}$; the proportion of 2-6 mm particles was only affected by the species. When it was significant, the cube location was the most important factor (Two-way ANOVA, Tab. 2). Regarding live fuel, the proportion of leaves in Pyracantha coccinea was significantly lower than that in the other species but the proportion of 2-6 $\mathrm{mm}$ particles was the highest in this species. The proportion of particles $<2 \mathrm{~mm}$ in Phyllostachys $s p$. was significantly higher than that in the other species. The proportion of particles $>6 \mathrm{~mm}$ was significantly higher in Prunus laurocerasus and Nerium oleander than in Phyllostachys sp., Cupressus sempervirens and Pyracantha coccinea (Fig. 4). The proportions of leaves, particles $<2 \mathrm{~mm}$ and $>6 \mathrm{~mm}$ significantly differed between the cube locations (Fig. 5); top cubes presenting the highest proportions of leaves and particles $<2 \mathrm{~mm}$ and base cubes the 
Author-produced version of the article published in Environmental Management, 2013, vol. 52, pp 467-480

Original publication available at http://www.springer.com

doi : 10.1007/s00267-013-0067-z99

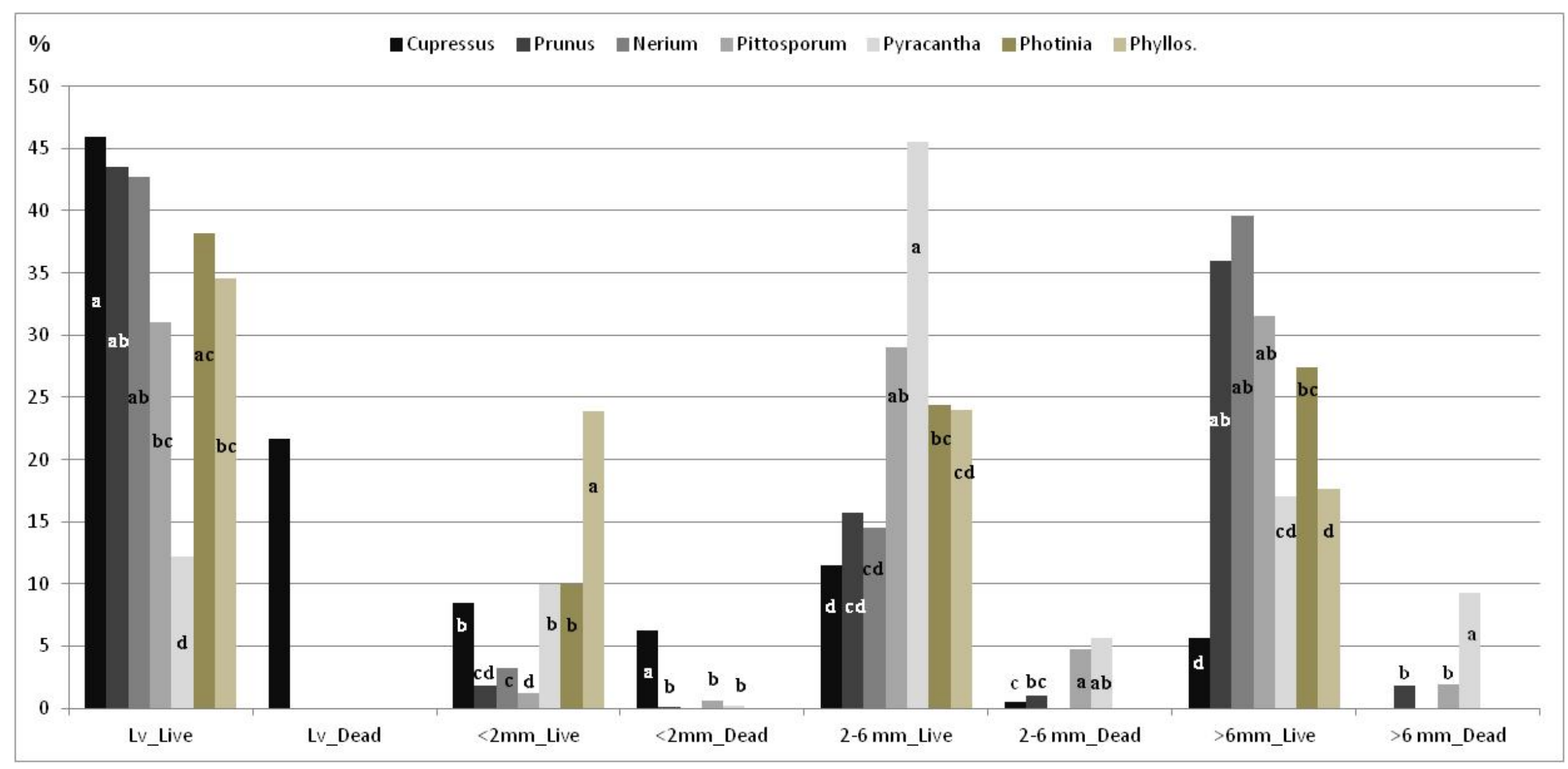

Fig. 4 Proportions of the different classes of particle in the seven species studied (Phyllos.: Phyllostachys sp.). Different letters on the same bar indicate significant differences according to two-way ANOVA Fisher test for live particles and one-way ANOVA Kruskal-Wallis test for dead particles 
Author-produced version of the article published in Environmental Management, 2013, vol. 52, pp 467-480

Original publication available at http://www.springer.com

doi : 10.1007/s00267-013-0067-z1010

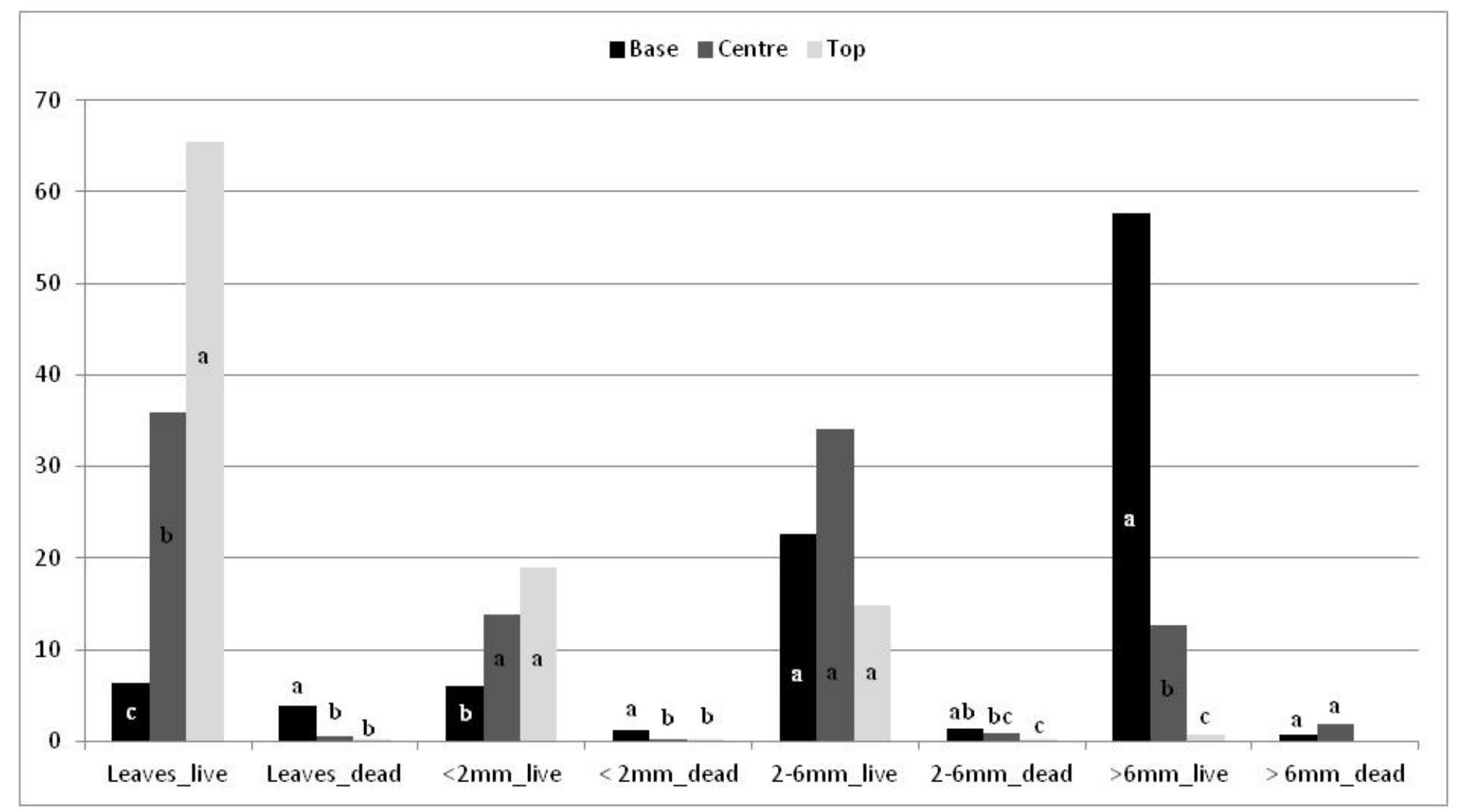

Fig. 5 Proportions of the different classes of particles in the three cube locations. Different letters on the same bar indicate significant difference according to two-way ANOVA Fisher test for live particles and one-way ANOVA Kruskal-Wallis test for dead particles 
other highest proportion of particles $>6 \mathrm{~mm}$. Centre cubes presented higher proportion of 2-6mm particles than the location (Fig.5). The proportions of live and dead particles that differed significantly between species are presented in Figure 4 and the proportions of live and dead particles that differed significantly between cube locations are shown in Figure 5. Regarding live fuel, the proportion of leaves was significantly higher in the top cubes and regarding dead fuel, the proportion of very fine particles was significantly higher in the base cubes.

The interaction between the species and the cube location was significant in all the classes of particles except in the $>6 \mathrm{~mm}$ class (Two-way ANOVA, Tab. 2). Regarding live leaves, the effect of the cube location was not significant for Pyracantha coccinea and Cupressus sempervirens and it was significant only for Photinia fraseri regarding the particles $<2 \mathrm{~mm}$. Regarding the $2-6 \mathrm{~mm}$ particles, the species significantly interacted with the top cubes only (Fig. 6).

The species had always a significant effect on the proportions of the different classes of dead particles while the cube location significantly affected the proportion of 2-6 mm particles (One-way ANOVA, Tab. 2). Regarding dead fuel, cubes sampled in Cupressus sempervirens presented significantly higher proportions of very fine fuel (leaves and particles $<2 \mathrm{~mm}$ ) than the other species.

\subsection{Flammability experiments with the epiradiator}

The flammability experiments performed on the live leaves of the different species showed that Phyllostachys sp. and Photinia fraseri were the most flammable species (short time-to-ignition, high ignition frequency and flaming duration), while Pittosporum tobira was the least flammable species (long time-to-ignition and low ignition frequency) according to Valette's classification (1990). Results also showed that, regarding live leaves, Cupressus sempervirens was among the least flammable species despite its high ignition frequency (Table 3) but the dead leaves of this species were the most flammable particles (IF $=100 \%$, TTI $<3$ s and FD $>15 s$ ), regardless of the flammability variables and of the species. Because of this, data on dead leaves have not been taken into account in the ANOVAs.

ANOVAs performed on the data recorded during these experiments showed that the species had a highly significant effect on flammability variables obtained with this experimental device, especially on time-toignition (Table 3). The ignition frequency of Pittosporum tobira leaves was significantly lower than that of leaves of the other species, while the ignition frequency of Photinia fraseri leaves was significantly higher than that of Nerium oleander and Pyracantha coccinea leaves. Furthermore, Prunus laurocerasus leaves ignited more 
Author-produced version of the article published in Environmental Management, 2013, vol. 52, pp 467-480

Original publication available at http://www.springer.com

doi : 10.1007/s00267-013-0067-z1212
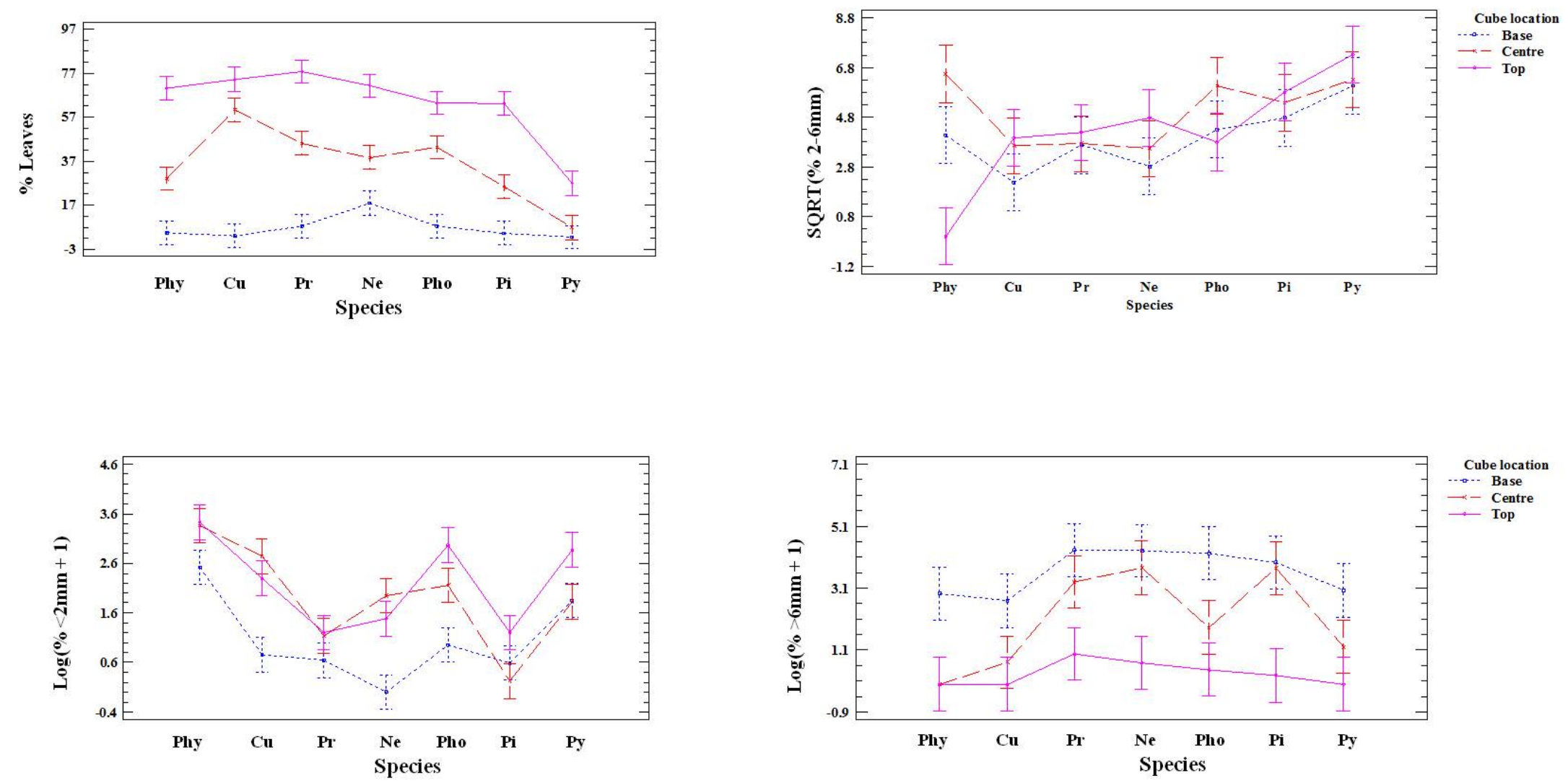

Fig. 6 Interactions (and 95\% Fisher LSD interval) between cube location and species for the different classes of live particles (Phy: Phyllostachys sp., Cu: Cupressus sempervirens, Ne: Nerium oleander, Pho: Photinia fraseri, Pi: Pittosporum tobira, Pr: Prunus laurocerasus and Py: Pyracantha coccinea) 
frequently than those of Nerium oleander. The time-to-ignition was shorter for Phyllostachys $s p$. leaves than for the the others, while Cupressus sempervirens leaves took the longest time to ignite. The time-to-ignition did not vary significantly between Photinia fraseri and Pyracantha coccinea, or between Prunus laurocerasus and Pyracantha coccinea. Prunus laurocerasus and Cupressus sempervirens leaves burned significantly faster than that of the other species, but the flaming duration of Cupressus sempervirens leaves was not significantly lower than that of Pyracantha coccinea leaves.

\subsection{Gross heat of combustion}

The gross heat of combustion (GHC) of very fine fuels (measured by calorimetry) was the highest in Nerium oleander and Photinia fraseri leaves and the lowest in Phyllostachys sp. leaves (Table 5). The GHC of twigs $<2$ $\mathrm{mm}$ in diameter in this latter species was the highest and it was the lowest in Prunus laurocerasus. The species had a significant effect on GHC of twigs $<2 \mathrm{~mm}$ in diameter, but not on GHC of leaves (Table 4). GHC of twigs $<2 \mathrm{~mm}$ in diameter did not differ between Nerium oleander and both Pittosporum tobira and Prunus laurocerasus, nor between Pittosporum tobira and Prunus laurocerasus as well as between Photinia fraseri and Pyracantha coccinea.

\subsection{Classification of species}

The cloud plot extracted from the co-inertia analysis (Fig. 7) showed the position of the dependent variables (flammability variables) and of the explanatory variables (leaf traits and GHC). Axis 1 explained 58\% of variance and differentiated species presenting high ignitability (Photinia fraseri, Phyllostachys sp. and Pyracantha coccinea), characterised by high foliar surface area-to-volume ratio, from species presenting lower ignitability characterised by high GHC (Pittosporum tobira, Nerium oleander, Cupressus sempervirens). Axis 2 explained $42 \%$ of variance and opposed species with short flaming duration (Cupressus sempervirens and Prunus laurocerasus), characterised by thick leaves and low foliar surface area-to-volume ratio with species presenting higher sustainability and ignitability (Photinia fraseri, Phyllostachys sp.).

Hierarchical cluster analysis of the flammability variables (ignition frequency, time-to-ignition and flaming duration) categorized the relative flammability of the seven species (including dead Cupressus sempervirens) in five clusters of species (Fig. 8): (i) poorly flammable (Pittosporum tobira), (ii) not very flammable (live Cupressus sempervirens), (iii) moderately flammable (Pyracantha coccinea, Nerium oleander and Prunus laurocerasus), (iv) highly flammable (Photinia fraseri and Phyllostachys sp.) and (v) extremely flammable (dead Cupressus sempervirens). 


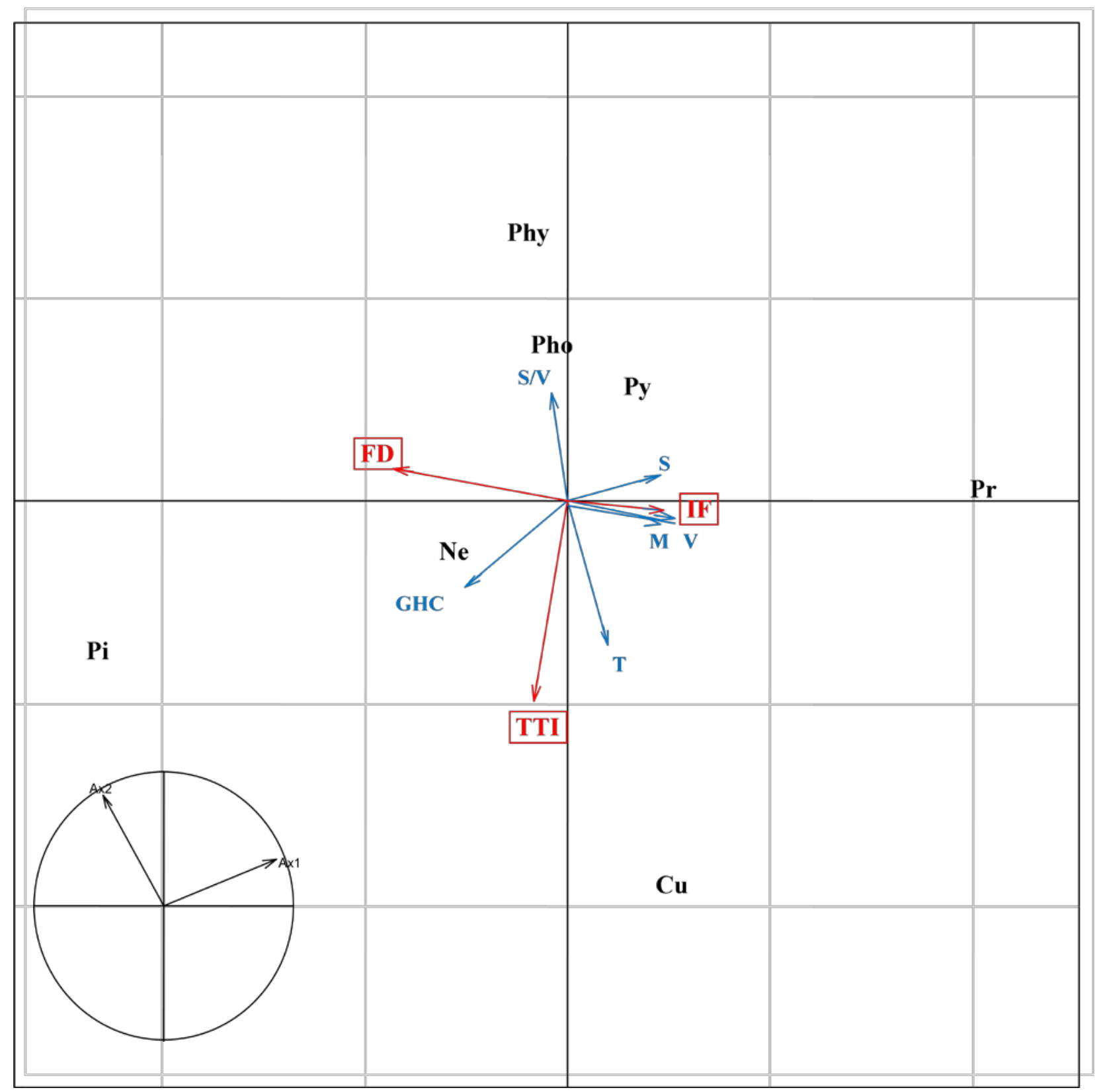

Fig. 7 Results of the co-inertia analysis performed on the leaf traits (M: mass, S: surface area, V: volume, S/V: surface area to volume ratio, T: thickness) and Gross Heat Content (GHC) values as explanatory variables and on the flammability variables (TTI: time-to-ignition, FD: flaming duration, IF: ignition frequency) as dependent variables giving the position of species (Phy: Phyllostachys sp., Cu: Cupressus sempervirens, Ne: Nerium oleander, Pho: Photinia fraseri, Pi: Pittosporum tobira, Pr: Prunus laurocerasus and Py: Pyracantha coccinea) on the co-inertia Factor 1 x Factor 2 plane 


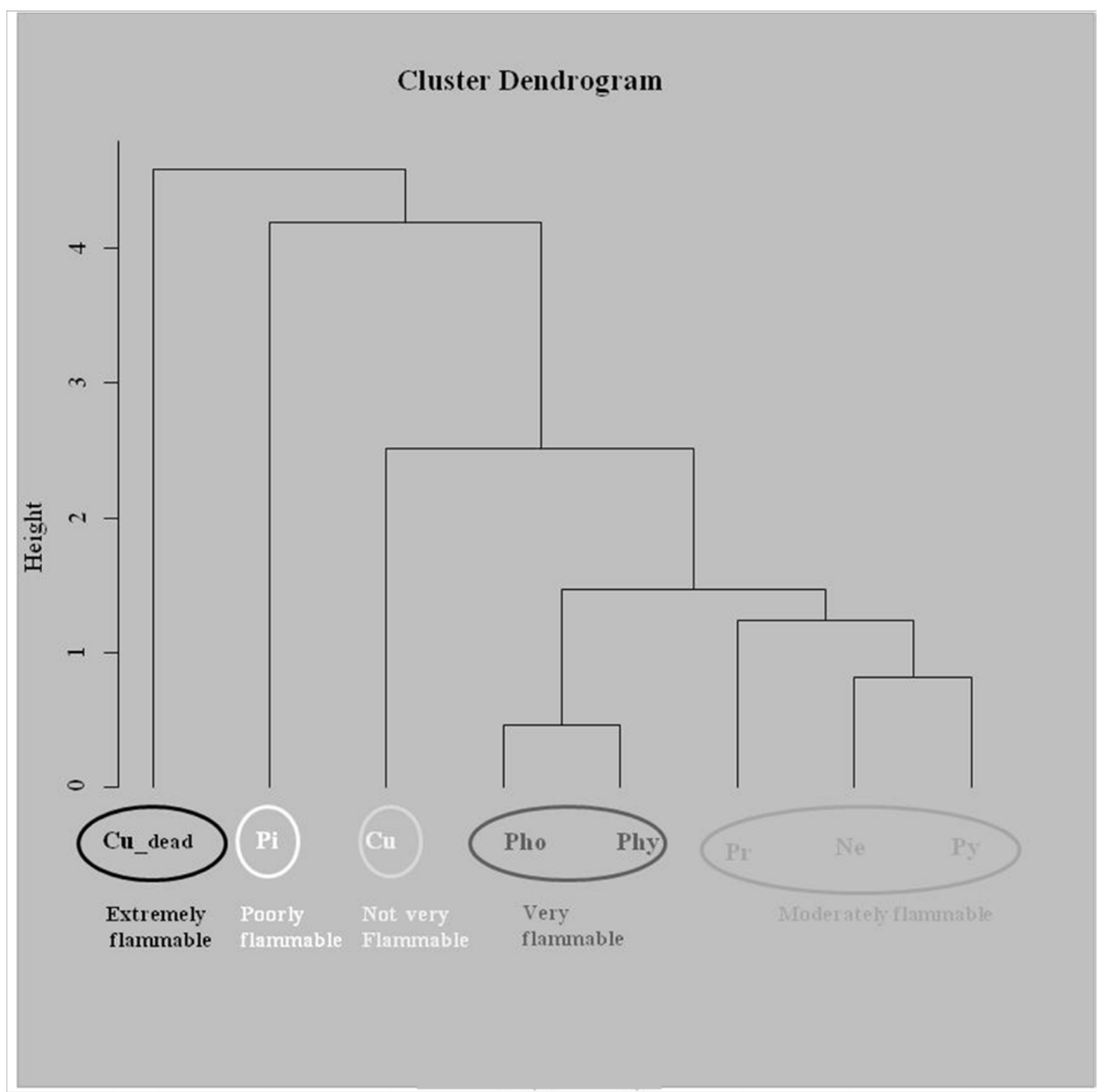

\section{Discussion}

In this work, plant flammability was assessed through the measurement of physical characteristics such as the bulk density or the proportion of each class of particle composing the plant canopy and through the measurement of the gross heat content of these particles as well as through the measurements of the flammability variables (ignition frequency, time-to-ignition and flaming duration) when leaves of each species were burned.

\subsection{Effects of species on the proportion of particles and on their size}

A two-way ANOVA was used to assess the effects of the cube location and of the species on the proportions of the different classes of particles. These proportions were significantly influenced by the species and, except for the 2-6mm class, by the cube location. However, there is evidence of a significant interaction between the two 
factors, except for the class of particles $>6 \mathrm{~mm}$. Thus, it is worth noting that, when it was significant, the cube location had an effect that varied between the different species.

The sorting of the cubes sampled in the three locations of the plant canopy showed that the amount of live particles, which were mainly located at the periphery of the canopy (top and centre cubes), was much greater than that of dead particles, which were located more in depth in the canopy (base cube). Live fuel was mainly composed of leaves and particles $<2 \mathrm{~mm}$ in diameter contrary to dead fuel which was mainly composed of particles $>6 \mathrm{~mm}$ in diameter except for Cupressus sempervirens samples in which dead leaves dominated. Retention of fine dead fuel within the plant structure has been observed in several Australian fire-prone species (Specht et al. 1958, Moore and Keratis 1971, Dickinson and Kirkpatrick 1985), in the european gorse, Ulex europeus (Baeza et al. 2006) or in the American chamise Adenostoma fasciculatum (Schwilk 2003) and fire performance is affected by the fraction of dead fuel because of its low water content (Elvira and Hernando 1989; Babrauskas 2003), which in ornamental vegetation is related to the age, health and maintenance of the plants. Thus, the great amount of dead leaves within the canopy of Cupressus sempervirens would confer high flammability to this species. Moreover, several studies have shown that fuel size affects the potential amount of fuel that would combust in a wildfire, with fine fuel being more flammable than coarse fuel (e.g. Bond and Van Wilgen 1996; Baeza et al. 2002) because fine particles ignite more readily and release their heat more quickly than do thicker particles of an equivalent total weight (Wilson 1992). As the bulk density of branches and leaves, determines the rate of oxygen flow through the fuels as well as the heat transfer between fuel elements (Scarff and Westoby 2006), flammability mainly depends on the physical arrangement of the plant biomass (Doran et al. 2004). Thus, flammability would be high for hedges composed of species such as Pyracantha coccinea or Phyllostachys $s p$ which are the species with the lowest bulk densities of particles. It is worth noting that, except for $C$. sempervirens and $P$. coccinea, the species with high proportion of a given class of particle were not the species with high bulk density of this class.

\subsection{Effect of species on flammability of leaves}

Flammability of live leaves (and of dead leaves of Cupressus sempervirens) was assessed by epiradiator tests. Live leaves of species presenting the higher moisture content had longer time-to-ignition (Nerium oleander, Pittosporum tobira and Prunus laurocerasus) and those presenting the lowest moisture content were the most flammable (higher ignitability and sustainability), especially live leaves of Photinia fraseri and Phyllostachys sp. and dead leaves of Cupressus sempervirens. Currently, there is no work on the assessment of the flammability of ornamental species using such a burning device. Data analyses showed that the species significantly affected the different flammability variables, partly through their leaf moisture content. In addition to the burning experiments, it would have been interesting to perform analyses of the volatile organic compounds of the leaves. Indeed, Brown et al. (1982) showed that the flammability of fine fuel from different species may differ because of differences in physical and chemical attributes. Contrary to Alessio et al. (2008), Ormeño et al. (2009), who used the same burning protocol as ours, showed that the species significantly affected flaming duration but not time-to-ignition and that ignitability was favoured by high terpene content in contrast to flaming duration. Theses authors worked on litter beds which had lower FMC than live fuels entailing shorter time-to-ignition values (between 2 and 4s) which were in the same range as those of dead leaves of Cupressus sempervirens recorded in the present work. This was also the case with the work of Pellizzaro et al. (2007) who compared the flammability of twigs of different species whose moisture contents were lower than that of leaves. Nevertheless, regarding time-to-ignition of live leaves, our results were in the same range as those of Valette (1990) who also worked on live leaves using the same burning protocol.

According to Valette's classification, which takes into account ignition frequency and time-to-ignition, the different species were ranked from slightly flammable (Pittosporum tobira) to extremely flammable (Phyllostachys sp.); Nerium oleander and, surprisingly, live leaves of Cupressus sempervirens were not ranked as very flammable (Table 4), even if they are known to contain great amount of volatile oils. These results agreed with those of Etlinger and Beall (2004) who also found that Nerium oleander was not a very flammable species, and it could therefore be recommended for planting in WUIs. In the present study, Cupressus sempervirens displayed the longest time-to-ignition (among the species tested), contrary to the results reported by Liodakis et al. (2002), who found that this latter species was one of the most flammable (of the species tested) 
according to its short ignition delay. This different result could be explained, as the ignition device used in these authors' work differed from that used in the present study. Our results also showed that flaming duration was shortest for Prunus laurocerasus leaves and highest for Pittosporum tobira leaves what was difficult to explain through the leaf moisture content as both species presented high foliar moisture content. In this case, analyses of the foliar chemical content could have given more information for explaining this latter result as, according to Behm et al. (2004), chemical components may play a role in the fire sustainability of a plant.

\subsection{Effect of species on gross heat of combustion of very fine particles}

Data analysis showed that the species had a significant effect on GHC of particles $<2 \mathrm{~mm}$ in diameter, but not on the GHC of leaves. According to the classification proposed by Elvira and Hernando (1989), the GHC values obtained for leaves of the species studied were generally "intermediate" $\left(18810-20900 \mathrm{~kJ} \mathrm{~kg}^{-1}\right)$, whereas the GHC values of the particles $<2 \mathrm{~mm}$ in diameter were either "low" (16720 -18809 kJ kg-1) (Prunus laurocesarus, Nerium oleander and Pittosporum tobira) or "intermediate" (Cupressus sempervirens, Pyracantha coccinea, Photinia fraseri and Phyllostachys sp.). For each species, except for Phyllostachys sp., the GHC was higher for leaves than for particles $<2 \mathrm{~mm}$ in diameter. A similar trend was observed by Dimitrakopoulos (2001) and Nuñez-Regueira et al. (1996) in Mediterranean species and it was attributed by to the fact that leaves constituted sites for accumulation of essential oils in plants. However, the gross heat of combustion of the ornamental species tested in our work was generally lower than that of common Mediterranean forest fuels (Madrigal et al. 2011). The heat of combustion of leaves of Cupressus sempervirens (19548 kJ kg-1) given by Liodakis et al. (2002), who worked on this species as a wildland species, was lower than that of other Mediterranean species but of the same order as those obtained in the present study (19108-19820 kJ kg$\left.{ }^{-1}\right)$.

\subsection{Classification of species}

Co-inertia analysis revealed that species with thin leaves were quick to ignite (Pyracantha coccinea, Phyllostachys sp.) and species with high leaf GHC burned the longest (Pittosporum tobira, Nerium oleander). This result is consistent with the findings of Behm et al. (2004), who reported species as highly consumable when they have high energy content. Usually, flammability characteristics are mainly affected either physical structure and physiological or cellular elements. From a physical perspective, foliage characteristics, especially the foliage mass, foliar moisture content and surface area-to-volume ratio of fuel particles are often considered significant factors in flammability (Fernandes and Rego 1998; Etlinger and Beall 2004). However, because we used a radiant disk (epiradiator) as burning device, foliar mass and volume should not be considered key variables for fire performance contrary to leaf surface area and thickness. Hierarchical classification revealed that Pittosporum tobira was the least flammable species according to the flammability variables, (ignition frequency, time-to-ignition and flaming duration). Dimitrakopoulos and Papaiannou (2001) ranked Nerium oleander as a low flammability species according to its time-to-ignition. In our experiment, this species also presented a long time-to-ignition but it was ranked as moderately flammable in the hierarchical analysis which combined its long time-to-ignition, intermediate ignition frequency and long flaming duration.

In their fuel classification, Dimitrakopoulos and Papaiannou (2001) highlighted four clusters of species according to their ignitability as a function of their foliage adaptations to prevent water loss. Contrary to our results, these authors ranked Cupressus sempervirens in the cluster of flammable species because of its short time-to-ignition due to high foliar surface area-to-volume ratio which facilitates heat absorption. Moreover, for these authors, high flammability was linked to richness in flammable volatile essential oils, what was not the case in the present work as none of the highly flammable species (Photinia fraseri or Phyllostachys sp.) are known to be aromatic plant species. According to the classification system described by Valette (1990), which takes into account only ignition frequency and time-to-ignition of leaves, and according to the results of the hierarchical classification, live leaves of Pittosporum tobira and Cupressus sempervirens were the least flammable (respectively rated 0 and 1, Tab. 4 and Fig. 7), particularly because of their longer time-to-ignition. However, dead C. sempervirens was the most flammable, regarding both classifications. Thus, according to this last result, flammability within a species can strongly vary according to the type of fuel tested (dead or live). 
This is confirmed by the work of Ganteaume et al. (2012) who assessed the flammability of the litters (dead surface fuels mainly composed of leaves) of the same ornamental species. These authors ranked litters of Cupressus sempervirens as moderately flammable (probably because of their high compaction), of Prunus laurocerasus as very flammable and of Phyllostachys $s p$ as not very flammable whereas they were ranked respectively as not very flammable, moderately flammable and very flammable in the current work.

\section{Conclusion}

In the present work, the flammability of seven ornamental species was assessed by their description at particle level and by the measurements of flammability variables during burning experiments on leaves. Gross heat of combustion and foliar physical characteristics helped to explain the flammability and these species were ranked in five clusters according to the ignitability and sustainability of their leaves. Pittosporum tobira, ranked as poorly flammable species, can be considered a fire-wise species while Phyllostachys sp. and Photinia fraseri ranked as highly flammable, should not be planted in WUI. Regarding the flammability of its live leaves, Cupressus sempervirens was not very flammable, however, because this species had the greatest amount of dead material which was ranked extremely flammable, this ornamental species that should be avoided in WUI, especially close to the houses. Further experiments, especially burning experiments of whole plants, are needed to confirm the present results and to make them more widely applicable. Moreover, protocols for determining flammability must be standardized, and a common classification must be established for the test results as stated by several works (Weise et al. 2005; White and Zipperer 2010).

Although laboratory experiments help improve our knowledge of the effects of live and dead fuel properties (species, moisture content and other physical and chemical characteristics) on flammability, the results obtained cannot be used directly to describe or predict the flammability of fuels under natural and real conditions; they represent basic information that is useful for assessing the fire risk of Mediterranean ornamental vegetation planted as hedges for instance. Moreover, White and Zipperer (2010) showed that flammability characteristics for a particular species were influenced not only by the species itself but also by their maintenance (watering, pruning, trimming, removing dead biomass, etc.) what could reduce the potential fire hazard. Indeed, routine irrigation, allowing the increase in FMC, has been shown to reduce plant flammability in wildland and WUIs (Narog et al. 1991; Doran et al. 2004), and pruning of dead wood decreases fire temperature and heat release (Schwilk 2003), indicating that plant flammability can be manipulated by horticultural practices.

\section{Acknowledgments}

The authors wish to thank the technical staff at Irstea (Roland Estève, Aminata N'Diaye, Fabien Guerra, JeanMichel Lopez, Marie Cabaret-Lampin, Florent Dalverny and Alice Lebeaux) and at INIA (Carmen Díez Galilea).

This study was funded by the French Ministry of Ecology (Service des Risques Naturels et Hydroliques) and the Direction Générale de la Prévention des Risques (DGPR). 


\section{References}

Asociación Española de Normalización y Certificación (2005) Biocombustibles sólidos. Método para la determinación del poder calorífico (UNE 164001 EX). Madrid

Alessio G, Peñuelas J, Lusia J, Ogaya R, Estiarte M, De Lillis M (2008) Influence of water and terpenes on flammability in some dominant Mediterranean species. Int J Wildland Fire 17:274-286

Anderson HE (1970) Forest fuel ignitability. Fire Tech 6:312-319

Babrauskas V (2003) Ignition handbook. Fire science publishers: Issaquah, WA

Baeza MJ, De Luis M, Raventos J, Escarre A (2002) Factors influencing fire behaviour in shrublands of different stand ages and the implications for using prescribed burning to reduce wildfire risk. Journal of Environmental Management 65:199-208

Baeza MJ, Raventos J, Escarré A, Vallejo VR (2006) Fire risk and vegetation structural dynamics in Mediterranean shrubland. Plant Ecology 187: 189-201. doi:10.1007/S11258-005-3448-4

Beall FC (2001) Fire-safe vegetation. In "Introduction to the I-Zone" pp.14.1-14.10. (UC Forest Products Laboratory. Richmond, CA)

Behm AL, Duryea ML, Long AJ, Zipperer WC (2004) Flammability of native understory species in pine flatwood and hardwood hammock ecosystems and implications for the wildland-urban interface. International Journal of Wildland Fire 13:355-365. doi:10.1071/ WF03075

Bond WJ, Van Wilgen BW (1996) Fire and plants. Chapman and Halls. London, UK

Brown JK, Oberheu RD, Johnston CM (1982) Handbook for inventory surface fuels and biomass in the interior west. Gen. Tech. Rep. INT-129. Ogden, UT: U.S. Department of Agriculture, Forest Service, Intermountain Forest and Range Experiment Station

Cardille JA, Ventura SJ, Turner MG (2001) Environmental and social factors influencing wildfires in the Upper Midwest, United states. Ecological Applications 11:111-127

Ching FT, Stewart WS (1962) Research with slow burning plants. Journal of Forestry 60:796-798

Cohen JD (2000) Preventing disaster: home ignitability in the wildland-urban interface. Journal of Forestry 98:15-21

Cohen M, Rigolot E, Etienne M (2002) Modeling fuel distribution with cellular-automata for fuel-break assessment. In 'Proceedings of IV international conference on forest fire research, 18-23 November 2002, Luso, Portugal. (Ed. DX. Viegas), (Millpress: Rotterdam)

Covington WW (2000) Helping western forests heal. Nature 408:135-136

Davis JB (1990) The wildland-urban interface: paradise or battleground? Journal of Forestry 88 (1):26-31

De la Riva J, Pérez-Cabello F (2005) El factor humano en el riesgo de incendios forestales a escala municipal. Aplicación de técnicas SIG para su modelización. In 'La ciencia forestal: respuestas para la sostenibilidad. 4• Congreso Forestal Español’. Sociedad Española de Ciencias Forestales, Madrid

De la Riva J, Pérez-Cabello F, Chuvieco E (2006) Wildland fire ignition danger spatial modelling using GIS and satellite data. In: EGU General Assembly-European Geosciences Union. Geophysical Research Abstracts 8:10321

Dickinson KJM, Kirkpatrick JB (1985) The flammability and energy content of some important plant species and fuel components in the forests of southeastern Tasmania. Journal of Biogeography 12:121-134

Dimitrakopoulos AP (2001) A statistical classification of Mediterranean species based on their flammability components. Int J Wildland Fire 10:113-118

Dimitrakopoulos AP, Papaioannou KK (2001) Flammability Assessment of Mediterranean Forest Fuels. Fire Tech 37:143-152

Dolédec S, Chessel D (1994) Co-inertia analysis; an alternative method for studying species-environment relationships. Freshwater Biology 31: 277-294

Doran JD, Randall CK, Long AJ (2004) Fire in the wildland-urban interface: selecting and maintaining fire-wise plants for landscaping. University of Florida, Institute of Food and Agricultural Services, Florida Cooperative Extension Service Circular 1445. (Gainesville, FL)

Elvira L, Hernando C (1989) Inflamabilidad y energía de las especies de sotobosque, Monografía INIA nº. 68, Madrid 
Etlinger MG (2000) Fire performance of landscape plants. MS Thesis, University of California, Berkeley

Etlinger MG, Beall FC (2004) Development of a laboratory protocol for fire performance of landscape plants. International Journal of Wildland Fire 13:479-488. doi:10.1071/WF04039

Fernandes PM, Rego F (1998) A new method to estimate fuel surface area-to-volume ratio using water immersion. Int J Wildland Fire 8:121-128

Ganteaume A., Jappiot M., Lampin C., 2012. Assessing the flammability of surface fuels beneath ornamental vegetation in wildland-urban interfaces, in Provence (Southeastern France). International Journal of Wildland Fire. doi 10.1071/WF12006

Hernando C (2000) Combustibles forestales: inflamabilidad. In 'La defensa contra incendios forestales, fundamentos y experiencias' (Vélez Muñoz, R. Ed.). McGraw-Hill. pp 3-6

Irby R, Beall FC, Barette B, Frago M (2000) "Wildland fire hazard assessment”. In Final report FEMA.. UC Forest Products Laboratory, Richmond, CA) pp. 1005-1047

Jappiot M, Blanchi R, Guarnieri F (2001) Traité IGAT "Information géographique et aménagement du territoire", Rubrique "Aménagement et gestion des territoires", Volume "Gestion spatiale des risques", Chapitre 6 "Systèmes d'information géographique et modélisation dans le domaine de la prévention des incendies de forêt". Editions Hermès, pp 145-181

Jappiot M, Lampin C, Curt T, Ganteaume A, Borgniet L, Bouillon C, Chandioux O, Estève R, Long M, Martin W, Morge D, Alexandrian D, D’Avezac H, Tatoni T, Dumas E, Valette J-C, Moro C (2007) Modélisation et cartographie de l'aléa d'éclosion d'incendie de forêt. Programme AIOLI. Convention DGFAR 61.45.80.31/04 1. Convention DPFM du 06 décembre 2005. Rapport final

Lampin-Maillet C (2009) Caractérisation de la relation entre organisation spatiale d'un territoire et risqué d'incendie: le cas des interfaces habitat-forêt du sud de la France. Thèse en géographie. Université de Provence

Lampin C, Jappiot M, Borgniet L, Long M (2006a) Cartographie des interfaces habitat-forêt: une approche spatiale pour estimer le risque d'incendie de forêt. European Journal of GIS and Spatial analysis 16(34):321-340

Lampin C, Jappiot M, Long M, Mansuy N, Borgniet L (2006b) WUI and road networks/vegetation interfaces characterizing and mapping for forest fire risk assessment. Forest Ecology and Management 234 (1):S42

Leone V, Koutsias N, Martínez J, Vega-García C, Allgöwer B, Lovreglio R (2003) The human factor in fire danger assessment. In: Chuvieco, E. (Ed.), Wildland Fire Danger Estimation and Mapping: The Role of Remote Sensing Data, World Sci., Hackensack, N.J., pp 143-196

Liodakis S, Bakirtzis D, Lois E (2002) TG and autoignition studies on forest fuels. Journal of Thermal Analysis and Calorimetry 69:519-528. doi:10.1023/A:1019907706137

Lubin DM, Shelly JR (Eds) (1997) Defensible space landscaping in the urban/wildland interface: a compilation of fire performance ratings of residential landscape plants. University of California, Forest Products Laboratory, Internal Report No. 36.01.137. (Richmond, CA)

Madrigal J, Marino E, Guijarro M, Hernando C, Díez C (2012) Evaluation of the flammability of gorse (Ulex europaeus L.) managed by prescribed burning. Annals of Forest Science 69(3):387-397. doi:10.1007/s13595-011-0165-0

Madrigal J, Guijarro M, Hernando C, Díez C, Marino E (2011) Effective heat of combustion for flaming combustion of Mediterranean forest fuels. Fire Technology 47(2):461-474. doi: 10.1007/s10694-010-0165-x

Martin RE, Gordon DA, Gutierrez ME, Lee DS, Molina DM, Schroeder RA, Sapsis DB, Stephens SL, Chambers M (1994) Assessing the flammability of domestic and wildland vegetation. In 'Proceedings of the $12^{\text {th }}$ conference on fire and forest meteorology', 26-28 October 1993, Jekyll Island, GA. pp. 130-137. (Society of American Foresters: Bethesda, MD)

Monroe MC, Long AJ, Marynowski S (2003) Wildland fire in the Southeast: Negotiating guidelines for defensible space. Journal of Forestry 101:14-19

Moore CWF, Keratis K (1971) Effect of nitrogen source on growth of Eucalyptus in sand culture. Australian Journal of Botany 19:125-141 
Moretti M, Legg C (2009) Combining plant and animal traits to assess community functional responses to disturbance. Ecography 32: 299-309

Narog MG, Paysen TE, Koonce AL, Burke GM (1991) Burning irrigated and unirrigated chamise. In 'Proceedings 11th conference on fire and forest meteorology, 16-19 April 1991, Missoula, MT.' pp. 352356. (Society of American Foresters: Bethesda, MD)

Nord EC, Green LR (1977) 'Low-volume and slow burning vegetation for planting on clearings in California chaparral.' USDA Forest Service Research Paper PSW-124. (Berkeley, CA)

Nuñez-Regueira L, Rodríguez-Añón JA, Proupín-Castiñeiras J (1996). Calorific values and flammability of forest species in Galicia. Coastal and hillside zones. Bioresource technology 57:283-289

Nuñez-Regueira L, Rodríguez-Añón JA, Proupín-Castiñeiras J (1997) Calorific values and flammability of forest species in Galicia. Continental high mountainous and humid Atlantic zones (NW Spain). Bioresource technology 61:111-119

Ormeño E, Céspedes B, Sánchez IA, Velasco-García A, Moreno J, Fernandez C, Baldy V (2009) The relationship between terpenes and flammability of leaf litter. Forest Ecology and Management 257:471-482

Pellizzaro G, Duce P, Ventura A, Zara P (2007) Seasonal variations of live moisture content and ignitability in shrubs of the Mediterranean Basin. International Journal of Wildland Fire 16:633-641

Petriccione M, Moro C, Rutigliano FA (2006) Preliminary studies on litter flammability in Mediterranean region. Forest Ecology and Management 234S

Scarff FR, Westoby M (2006) Leaf litter flammability in some semi-arid Australian woodlands. Functional Ecology 20:745-752

Schwilk DW (2003) Flammability is a niche construction trait: canopy architecture affects fire intensity. American Naturalist 162:725-733

Specht RL, Rayson P, Jackman ME (1958) Dark Island heath (Ninety-mile Plain, South Australia) - VI - Pyric succession: changes in composition, coverage, dry weight and mineral nutrient status. Australian Journal of Botany 6:59-88

Stephens SL (2005) Forest fire causes and extent on United States Forest Service lands. Int J Wildland Fire 14 :213-222. doi:10.1071/WF04006

Ter Braak CJF, Schaffers AP (2004) Co-correspondence analysis: a new ordination method to relate two community compositions. Ecology 85: 834-846

Thioulouse J, Chessel D, Doledec S, Olivier JM (1997) ADE-4: a multivariate analysis and graphical display software. Statistics and Computing 7: 75-83

Valette JC (1990) Inflammabilités des espèces forestières méditerranéennes. Conséquences sur la combustibilité des formations forestières. Revue Forestière Française, $\mathrm{n}^{0}$ spécial :76-92

Vélez R (1997) Recent history of forest fires in Mediterranean area. In: Balabanis P, Eftichidis G, Fantechi R (Eds.), Forest Fire Risk and Management. Proceedings of the European School of Climatology and Natural Hazards, Greece, 27 May-4 June 1992. European Commission, Brussels, pp. 15-26

Weise DR, White RH, Beall FC, Etlinger M (2005) Use of the cone calorimeter to detect seasonal differences in selected combustion characteristics of ornamental vegetation. Int J Wildland Fire 14:321-338. doi:10.1071/WF04035

White RH, Weise DR, Frommer S (1996) Preliminary evaluation of the flammability of native and ornamental plants with the cone calorimeter. In 'Proceedingsof the $21^{\text {st }}$ International Conference on Fire Safety', Milbrae, CA

White RH, Zipperer WC (2010) Testing and classification of individual plants for fire behaviour: plant selection for the wildland-urban interface. Int J Wildland Fire 19:213-227

White RH, Weise DR, Mackes K, Dibble AC (2002) Cone calorimeter testing of vegetation: an update. In 'Proceedings of the $35^{\text {th }}$ international Conference on Fire Safety', 22-24 July 2002, Columbus, OH. (Ed. CJ Hilado) pp. 1-12. (Products Safety Corporation: Sissonville, WV)

Wilson AAG (1992) Assessing fire hazard on public lands in Victoria: fire management needs and practical research objectives. Research report n³1, Department of Conservation and Environment (Australia). 
Author-produced version of the article published in Environmental Management, 2013, vol. 52, pp 467-480

Original publication available at http://www.springer.com

doi : 10.1007/s00267-013-0067-z2222

Table 1 Bulk density $\left(\mathrm{kg} \mathrm{m}^{-3}\right.$ ) of the very fine particles (leaves and particles $<2 \mathrm{~mm}$ ) in each cube location in the seven species studied (mean (standard deviation))

\begin{tabular}{|c|c|c|c|c|c|c|}
\hline & LIVE & & & DEAD & & \\
\hline & Base & Centre & Top & Base & Centre & Тор \\
\hline Cupressus & $0.44(0.44)$ & $3.72(2.64)$ & $3.71(3.34)$ & $10.36(11.25)$ & $0.70(0.62)$ & $0.053(0.033)$ \\
\hline Prunus & $0.30(0.36)$ & $3.72(1.26)$ & $2.28(2.42)$ & 0.025 & 0.050 & - \\
\hline Nerium & $0.80(0.22)$ & $0.82(0.78)$ & $2.51(2.50)$ & - & - & - \\
\hline Pittosporum & $0.14(0.11)$ & $1.06(0.69)$ & $2.28(2.42)$ & $0.11(0.11)$ & 0.025 & - \\
\hline Pyracantha & $0.18(0.13)$ & $0.19(0.077)$ & $0.59(0.26)$ & 0.012 & $0.037(0.018)$ & - \\
\hline Phyllostachys & $0.12(0.098)$ & $0.29(0.11)$ & $0.52(0.24)$ & - & - & - \\
\hline
\end{tabular}

Table 2 Results of the statistical analysis performed on the proportions of each class of particle compared across species and cube location (For the two-way ANOVAs, the $<2 \mathrm{~mm}, 2-6 \mathrm{~mm}$ and $>6 \mathrm{~mm}$ classes were transformed $(\log (\mathrm{x}+1)$ for $<2 \mathrm{~mm}$ and $>6 \mathrm{~mm}$ classes and squareroot $(\mathrm{x})$ for $2-6 \mathrm{~mm}$ class, italic $=$ not significant) 
Author-produced version of the article published in Environmental Management, 2013, vol. 52, pp 467-480

Original publication available at http://www.springer.com

doi : 10.1007/s00267-013-0067-z2323

\begin{tabular}{|c|c|c|c|c|c|}
\hline & & Leaves & $<2 \mathrm{~mm}$ & $2-6 \mathrm{~mm}$ & $>6 \mathrm{~mm}$ \\
\hline Live particles & Species & $\mathrm{F}=28.08, \mathrm{p}<0.0001$ & $\mathrm{~F}=35.04, \mathrm{p}<0.0001$ & $\mathrm{~F}=6.58, \mathrm{p}<0.0001$ & $\mathrm{~F}=5.85, \mathrm{p}=0.0002$ \\
\hline \multirow[t]{2}{*}{ Two-way ANOVA } & Cube & $\mathrm{F}=401.82, \mathrm{p}<0.0001$ & $\mathrm{~F}=42.41, \mathrm{p}<0.0001$ & $F=3.19, p=0.0512$ & $\mathrm{~F}=52.61, \mathrm{p}<0.0001$ \\
\hline & Interaction & $\mathrm{F}=7.48, \mathrm{p}<0.0001$ & $\mathrm{~F}=4.26, \mathrm{p}=0.0002$ & $F=3.38, p=0.0017$ & $F=1.29, p=0.26$ \\
\hline Dead particles & Species & $K W=46.29, p<0.0001$ & $K W=25.02, p=0.0003$ & $K W=20.89, p=0.0019$ & $K W=15.66, p=0.015$ \\
\hline One-way ANOVA & Cube & $K W=1.46, p=0.48$ & $K W=3.95, p=0.14$ & $K W=8.54, p=0.014$ & $K W=4.19, p=0.123$ \\
\hline
\end{tabular}


Author-produced version of the article published in Environmental Management, 2013, vol. 52, pp 467-480

Original publication available at http:/WwW springer.com

doi : 10.1007/s00267-013-0067-z2424

Table 3 Leaf traits, flammability variables of live leaves (and dead leaves of Cupressus sempervirens ${ }^{1}$ ) and rating according to the classification of Valette (1990) for the species studied (Rating: 0 = slightly flammable; 1 = weakly flammable; 2 = moderately flammable; 3 = flammable; 4 = highly flammable; 5 = extremely flammable, FMC: fuel moisture content, N1: initial number of trials; N2: number of trials with ignition)

\begin{tabular}{|c|c|c|c|c|c|c|c|c|c|c|c|c|}
\hline Species & FMC (\%) & Mass (g) & $\begin{array}{c}\text { Contact surface } \\
\text { area }\left(\mathrm{cm}^{2}\right)\end{array}$ & $\begin{array}{c}\text { Thickness } \\
\text { (cm) }\end{array}$ & $\begin{array}{l}\text { Volume } \\
\text { (cm3) }\end{array}$ & $\begin{array}{l}\text { Surface/Volume } \\
\qquad\left(\mathrm{cm}^{-1}\right)\end{array}$ & N1 & $\begin{array}{c}\text { Ignition } \\
\text { frequency (\%) }\end{array}$ & N2 & $\begin{array}{l}\text { Time-to- } \\
\text { ignition (s) }\end{array}$ & $\begin{array}{c}\text { Flaming } \\
\text { duration (s) }\end{array}$ & Rating \\
\hline Cupressus sempervirens & 150 & $0.42(0.08)$ & $6.9(1.10)$ & $0.093(0.10)$ & $0.51(0.12)$ & $13.82(1.23)$ & 50 & $94(24)$ & 47 & $35.55(6.61)$ & $6.51(2.72)$ & 1 \\
\hline C. sempervirens (dead) & 6 & $0.23(0.04)$ & $6.0(1.10)$ & $0.075(0.003)$ & $0.35(0.06)$ & $16.94(0.61)$ & 50 & 100 & 50 & $2.58(0.93)$ & $15.52(4.02)$ & 5 \\
\hline Nerium oleander & 213 & $0.96(0.19)$ & $23.4(2.5)$ & $0.044(0.006)$ & $1.03(0.22)$ & $23.36(3.61)$ & 50 & $86(35)$ & 42 & $23.67(6.81)$ & $8.14(4.20)$ & 2 \\
\hline Photinia fraseri & 92 & $0.76(0.20)$ & $25.3(2.4)$ & $0.038(0.002)$ & $0.95(0.13)$ & $26.69(1.71)$ & 50 & 100 & 50 & $14.96(2.09)$ & $8.26(3.13)$ & 4 \\
\hline Phyllostachys sp. & 117 & $0.094(0.02)$ & $10.6(1.8)$ & $0.027(0.031)$ & $0.28(0.31)$ & $37.89(1.06)$ & 50 & $96(20)$ & 48 & $10.71(4.15)$ & $8.75(3.18)$ & 5 \\
\hline Pittosporum tobira & 178 & $0.43(0.05)$ & $13.2(1.6)$ & $0.032(0.002)$ & $0.43(0.05)$ & $31.09(2.10)$ & 50 & $46(50)$ & 23 & $29.56(11.73)$ & $8.96(6.80)$ & 0 \\
\hline Prunus laurocerasus & 178 & $1.68(0.27)$ & $46.6(7.5)$ & $0.042(0.003)$ & $1.98(0.41)$ & $23.86(1.73)$ & 50 & $98(14)$ & 49 & $17.43(4.27)$ & $4.92(2.04)$ & 4 \\
\hline Pyracantha coccinea & 108 & $0.069(0.02)$ & $4.3(0.5)$ & $0.016(0.004)$ & $0.07(0.02)$ & $64.81(11.82)$ & 50 & $88(33)$ & 44 & $15.86(5.70)$ & $7.11(4.99)$ & 3 \\
\hline Results of statistical & & & & & & & & $K W=91.84$ & & $K W=203.26$, & $\mathrm{KW}=46.35$, & \\
\hline tests & & & & & & & & $\mathrm{p}<0.0001$ & & $\mathrm{p}<0.0001$ & $\mathrm{p}<0.0001$ & \\
\hline
\end{tabular}

\footnotetext{
${ }^{1}$ Not taken into account in the statistical tests
} 
Author-produced version of the article published in Environmental Management, 2013, vol. 52, pp 467-480 Original publication available at http://www.springer.com

doi : 10.1007/s00267-013-0067-z2525

Table 4 Gross heat of combustion (GHC, in $\mathrm{kJkg}^{-1}$ ) of very fine fuels in the seven species studied (Lv: leaves, NA: no data, italic: not significant)

\begin{tabular}{|c|c|c|c|c|}
\hline Species & GHC_Lv_live & GHC_2 mm_live & GHC_Lv_dead & GHC_2 mm_dead \\
\hline Cupressus sempervirens & 19819 & 19108 & 19265 & 19223 \\
\hline Nerium oleander & 20067 & 18172 & NA & NA \\
\hline Photinia fraseri & 20031 & 18859 & NA & NA \\
\hline Phyllostachys sp. & 18704 & 19676 & NA & NA \\
\hline Pittosporum tobira & 19929 & 18134 & NA & NA \\
\hline Prunus laurocerasus & 18797 & 18084 & NA & NA \\
\hline Pyracantha coccinea & 19358 & 18905 & NA & NA \\
\hline Results of statistical tests & $K W=12.57, p=0.0503$ & $K W=13.93, p=0.0303$ & & \\
\hline
\end{tabular}

